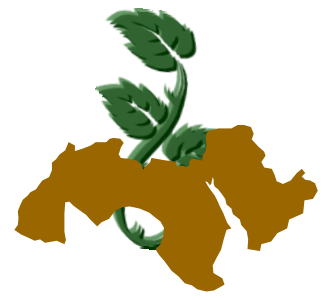

Arab Univ.

\title{
EVALUATION OF ENRICHED COMPOST AND ITS ROLE IN SYNERGY WITH RHIZOBACTERIA AND N-FERTILIZATION FOR IMPROVING MAIZE PRODUCTIVITY IN SANDY SOIL
}

\author{
Abdel-Wahab ${ }^{1}$, A.F.M. \\ 1- Soils, Water and Environment Res. Inst.; Agric. Res. Center, Giza, Egypt.
}

Keywords: Enriched compost, Maize, Mineral fertilization

\begin{abstract}
Chopped rice straw supplemented with different amendments, namely organic (farmyard manure and vinass); bio (mixture of Trichoderma harzianum and Trichoderma viridi) and mineral (rock phosphate, bentonite, elemental sulfur and commercial nitric acid) to prepare enriched compost. After elapsing of composting process the prepared compost was monitored for its physio-chemical and microbiological characteristics as well as some maturity indices. Afterwards, enriched compost was evaluated in synergy with rhizobacteria (mixture of Serratia sp and Paenibacillus polymyxa) and graded levels of $\mathrm{N}$-fertilizer as integrated fertilizer strategy for improving the growth and productivity of maize plants grown in sandy soil through two field experiments executed at Ismailia Agriculture Research Station during successive summer season of 2005 and 2006. Results of enriched compost monitoring revealed that this product has an acceptable degree of the main physio-chemical properties such as color, bulk density, WHC, $\mathrm{pH}$, $\mathrm{EC}$ and $\mathrm{C} / \mathrm{N}$ ratio. Also, enriched compost exhibited a valuable degree of fertilizer value, which reflected by its content from macro and micronutrients. This end product has a high degree of microbiological traits, which exhibited through the high counts of the main groups of microorganism and remarkable values of dehydrgenase and nitrogenase activities. In addition, all examined maturity indices exerted that this product has a reasonable degree of maturity and it can applied to plants without causing phytotoxicity or immobilization. Results of field experiments showed that growth aspects of maize plants were extremely affected by the mineral fertilization rather than organic and/or
\end{abstract}

bio one. However, the highest values of plant vigor and $\mathrm{N}$-content were attained as a results of the integrated fertilization strategy, particularly when maize plants received $120 \mathrm{~kg} \mathrm{~N} /$ fed in combination with compost (at rate of 5 ton/fed) and rhizobacteria. The maize yield and its attributes appeared high response to applied $\mathrm{N}$-fertilizer levels and organic fertilization. Irrespective of bio-organic fertilization, addition of $\mathrm{N}$-fertilizer at levels of 60,90 and $120 \mathrm{~kg} \mathrm{~N} / \mathrm{fed}$ led to increase the grain yield by $103.70,141.12$ and $174.77 \%$, respectively over control treatment (30 kg N/fed). On the other hand, topdressing of soil with enriched compost led to increase the grain yield of maize by $19.70 \%$ and this percentage increase raised to $25.76 \%$ when the organic manuring was conjugated with rhizobacteria under any level of $\mathrm{N}$-fertilizer. However, the highest yield of maize was achieved in case of synergy between the high dose of $\mathrm{N}$-fertilizer and 5 ton/fed from enriched compost for rhizobacterial inoculated grains.

\section{INTRODUCTION}

The organic matter content in Egyptian soils does not exceed than $2 \%$ due to arid climate and dominancy of basic soil conditions, which leading to raise the decomposition rate of applied organic manures, particularly in desert soils. These soils have unfavorable structure and low capacity to retain water and nutrients, the $\mathrm{pH}$ is grater than 7.5 due to the presence of $\mathrm{CaCO}_{3}$. In addition organic matter resources are relatively limited. Moreover, the sustainable providing with organic matter to Egyptian soils is very essential affair, particularly under the intensive cropping system.

According to the early salient motto introduced by Riad (1982), he declared that "what comes out of the soil, must be returned to the soil" hence, the agricultural residues represents the consistent and 
safe resources of organic matter for Egyptian soils, with highlighting on rice straw, which produces in huge quantities resulting in a tremendous environmental problems such as the black clouds resulted from the burning of rice straw in open farms. However, there are many disadvantages from using the plant residues for direct application to soil, particularly in case of their using in organic fertilization (Mathur et al 1993). Therefore, a proper piling and composting of crop residues before their incorporation to the field is sensible agricultural policy to overcome the problems associated with disposal of biodegradable matter in soil (Senesi, 1989). Composting is a process of controlled biological decomposition of biodegradable materials under managed conditions that are predominantly aerobic and that allow the development of thermophilic temperatures as a result of biologically produced heat in order to achieve biologically stable, safe and plant sanitized compost. The heterogeneous organic matter in the starting materials is transformed after suitable composting period (which include bio-oxidative and maturation phases) into a stabilized end product through partial mineralization and humification. Also, composting include killing of pathogen and weed seeds and improving handling characteristics by reducing the volume and weight of produced compost (Rynk, 1992 and Rodrigues et al 1995). However, composting has some drawbacks, including their relatively low levels of nutrients $(1-2 \% \mathrm{~N}$ and less than $1 \% \mathrm{P}$ ) as compared to complete fertilizer and the mineralization rates of the macronutrients generally are law leading to increase the compost application rates to satisfy the complete $\mathrm{N}$ or $\mathrm{P}$ requirements (Egball and Power, 1999). Nevertheless, such problems seemed to be solved by two main ways, by enriching of composted materials via blending several sources of crop residues differed in their physical and chemical properties with some amendments such as rocks, minerals, animal wastes and beneficial microorganisms, which each of them must be applied at relevant stages of composting process. Such amendments may lead to accelerate the decomposition rate, correct the nutrients deficiency and increase the ability of produced compost for bio-protecting of plants against phytopathogens (Abdel-Wahab, 1999 and AbdelWahab \& Ahmed, 2003). Another way, which may be accomplished in parallel with the previous one, may be achieved by combining of compost with inorganic fertilizers to magnify the nutrients use efficiency. Generally, organic fertilizers are traditionally applied at rates to meet crop- $\mathrm{N}$ require- ments since it's often the most limiting factor of crop productivity. Many researchers showed that nitrogen use efficiency is greatest from combination of organic and inorganic fertilizers (Sikora \& Enkiri, 2000; Smith et al 2001 and Keeling et al 2003).

Plant growth promoting rhizobacteria (PGPR) are beneficial soil bacteria that colonize plant roots and resulted in increased plant growth. Both Grampositive and Gram-negative bacteria have been found to have direct and/or indirect PGPR effects (Bertrand et al 2001). The direct mechanisms of increasing plant growth by PGPR include the provision of bio-available phosphorus for plant uptake, nitrogen fixation for plant use, sequestration of iron for plants by siderophores, production of phytohormones and modifying of plant ethylene levels (Glick et al 1999). Indirect mechanisms used by PGPR comprise antibiotics production against pathogenic organisms, reduction of iron availability to phytopathogens in the rhizosphere, synthesis of fungal cell lytic enzymes, inducing of systematic resistance and competition with detrimental microorganisms for sites on plant root (Van-Loon and Bakker, 2003). Rhizobacteria belonging to different genera, such as Azotobacter, Pseudomonas and Rhizobium have been reported to promote the growth of diverse plants such as wheat, maize, canola, soybean and vegetable plants (Abbass \& Okon, 1993 and Kokalis-Burelle et al 2006). Hence, the concept of integrated fertilizer management may extend to comprise the synergy between organic, mineral and bio-fertilizers to achieve the prospective target of sustainable agriculture system.

Therefore, the objectives of the current study were:- (i) to evaluate the traits of enriched compost made from rice straw; (ii) to investigate the more appropriate fertilization strategy for maize plants grown in sandy soil based on the integrated fertilization management including the organic, mineral and bio-fertilizers and their interactions

\section{MATERIALS AND METHODS}

\section{Preparation of enriched compost made of rice straw}

Enriched compost was prepared for two successive years (2005 and 2006) at Ismailia Agriculture Research Station, Ismailia Governorate. One ton of chopped rice straw was incorporated with farmyard manure, bentonite, urea and elemental sulfur at rate of $15,10,2.5$ and $1 \%$, respectively, at heap construction. After 30 days of heap construc- 
tion (at $2^{\text {nd }}$ turning), rock phosphate in highly fineness grad form was well incorporated with the composted materials at rate of $10 \%$, then Vinass at rate of $1 \%$ and commercial nitric acid $(60 \%)$ at rate of $0.5 \%$ were diluted in water $(100 \mathrm{~L})$ and thoroughly spread on the heap during the turning process. The main characteristics of the raw materials used are shown in Table (1).

Table 1. The main characteristics of the used raw materials

\begin{tabular}{|c|c|c|c|c|c|}
\hline Property & $\begin{array}{l}\text { Rice } \\
\text { straw }\end{array}$ & $\begin{array}{c}\text { Farm- } \\
\text { yard } \\
\text { manure }\end{array}$ & Vinass & $\begin{array}{c}\text { Rock } \\
\text { phosphate }\end{array}$ & Bentonite \\
\hline $\mathrm{pH}$ & 5.98 & 7.88 & 3.89 & 7.80 & 8.00 \\
\hline $\begin{array}{l}\mathrm{EC}(\mathrm{dS} / \mathrm{m} \\
\left.\text { at } 25^{\circ} \mathrm{C}\right)\end{array}$ & 4.70 & 3.61 & 12.82 & 3.07 & 5.16 \\
\hline Organic-C(\%) & 52.39 & 13.55 & 29.63 & 0.41 & 0.15 \\
\hline Total-N (\%) & 0.52 & 0.87 & 0.17 & 0.031 & 0.029 \\
\hline Total-P (\%) & 0.018 & 0.56 & 0.046 & 10.90 & 0.38 \\
\hline Total-K (\%) & 0.41 & 1.65 & 5.94 & 0.39 & 1.35 \\
\hline $\mathrm{C} / \mathrm{N}$ ratio & 100.75 & 15.57 & 174.29 & 13.23 & 5.17 \\
\hline $\mathrm{N}-\mathrm{NH}^{+}{ }_{4}(\mathrm{ppm})$ & 76.80 & 187.80 & 48.10 & 0.00 & 9.80 \\
\hline $\mathrm{N}-\mathrm{NO}_{3}{ }^{-}(\mathrm{ppm})$ & 41.30 & 79.40 & 23.50 & 0.00 & 0.00 \\
\hline Total-Fe (ppm) & 963.00 & 165.30 & 65.40 & $(0.59 \%)^{*}$ & $(4.80 \%)$ * \\
\hline $\begin{array}{l}\text { Total-Mn } \\
\text { (ppm) }\end{array}$ & 19.00 & 39.90 & 7.30 & $(0.036 \%)^{\star}$ & $(0.15 \%)$ * \\
\hline Total-Zn (ppm) & 13.00 & 27.80 & 17.80 & 82.30 & 73.20 \\
\hline Total-Cu (ppm) & 21.00 & 3.90 & 23.90 & 11.50 & 47.00 \\
\hline
\end{tabular}

* Values in parenthesis are percentage

Additionally, the composted materials were inoculated with mixture of Trichoderma harrzianum and Trichoderma viridi at rate of $400 \mathrm{~g}$ mycelia mat ( $200 \mathrm{~g}$ from each fungal inoculum), which applied at beginning and after 30 days of heap construction.

Compost heap constructed at dimensions of 2 $X 3 \times 1.5 \mathrm{~m}$ for width, length and height, respectively, by stowing the rice straw in successive layers on concreted floor. Each layer was provided with equal portion from the abovementioned amendments and received suitable water, then it well tamped. Heap turning was done every 15 days and the moisture kept always within the range of $40-60 \%$ by handing inspection along the composting process. Temperatures was fluctuated from 55 to up $65^{\circ} \mathrm{C}$ in the heap (within the core region and its adjacent zones) at active stage (60 days), then it decreased to range from $35-45^{\circ} \mathrm{C}$ during the last one month (curing stage).

\section{Compost sampling}

After elapsing the composting process (three months), three places were selected along the heap, namely at the top, meddle and bottom to collect representative samples. At each place, a hole was made and three samples were collected and combined. Compost on the surface and very bottom was avoided. The samples taken from the different places were then combined ( $\mathbf{W u}$ and $\mathbf{M a}$, 2001). Collected samples were air dried and then prepared for monitoring the physiochemical and microbiological traits as well as its maturity indices.

\section{Field experiment layout}

Two field experiments were executed at Ismailia Agriculture Research Station during the successive summer seasons of 2005 and 2006 to study the influence of enriched compost in combination rhizobacteria on the growth and productivity of maize plants grown in sandy soil under different levels of $\mathrm{N}$-fertilization using drip irrigation system. The main physical and chemical properties of experimental soil are presented in Table (2). Splitplot design with three replicates was used. The main plots were $\mathrm{N}$-fertilizer levels in ammonium sulfate form as follows:-

1- $30 \mathrm{Kg} \mathrm{N} /$ fed $\left(\mathrm{N}_{1}\right)$, applied in two doses.

2- $60 \mathrm{Kg} \mathrm{N} /$ fed $\left(\mathrm{N}_{2}\right)$, applied in four doses.

3- $90 \mathrm{Kg} \mathrm{N} / \mathrm{fed}\left(\mathrm{N}_{3}\right)$, applied in six doses.

4- $120 \mathrm{Kg} \mathrm{N} / \mathrm{fed}\left(\mathrm{N}_{4}\right)$, applied in eight doses.

The sub-plots were assigned to enriched compost and rhizobacteria treatments (bio-organic) as follows:-

a- Without bio-organic $\left(\mathrm{BO}_{1}\right)$.

b- 5 ton/fed enriched compost $\left(\mathrm{BO}_{2}\right)$.

c- Grain inoculation with rhizobacteria $\left(\mathrm{BO}_{3}\right)$.

d- Enriched compost plus rhizobacteria $\left(\mathrm{BO}_{4}\right)$.

All the experiment area was plowed and a diminutions of each plot was marked, then all amounts of enriched compost were added to the treated plots. Super-phosphate $\left(15.5 \% \mathrm{P}_{2} \mathrm{O}_{5}\right)$ at rate of $200 \mathrm{Kg} / \mathrm{fed}$ was added before sowing. Maize grains (Zea mays, cv. Hybrids Single 10) were sown at rate of two grains/hill at distance of $25 \mathrm{~cm}$ between each hill. Potassium sulfate $\left(48 \% \mathrm{~K}_{2} \mathrm{O}\right)$ was added at rate of $50 \mathrm{Kg} / \mathrm{fed}$ in two doses, the first is $1 / 3$ the amount was added with superphosphate and the second is $2 / 3$ the amount added at 70 days of sowing. The nitrogen was added as ammonium sulphate $(20.5 \% \mathrm{~N})$ and each $\mathrm{N}$ - 
level was allocated to equal doses, each dose equivalent $15 \mathrm{Kg} \mathrm{N} / \mathrm{fed}$, applied weekly according to the quantity of each $\mathrm{N}$-level.

Table 2. The main physical and chemical properties of soil used

\begin{tabular}{|c|c|}
\hline Soil property & Value \\
\hline Sand (\%) & 89.82 \\
\hline Silt (\%) & 6.43 \\
\hline Clay (\%) & 3.75 \\
\hline Texture grade & Sandy \\
\hline $\mathrm{CaCO}_{3}(\%)$ & 1.66 \\
\hline SP (\%) & 21.5 \\
\hline pH (soil paste) & 7.34 \\
\hline $\mathrm{EC}\left(\mathrm{dS} / \mathrm{m}\right.$ at $\left.25^{\circ} \mathrm{C}\right)$ & 0.38 \\
\hline \multicolumn{2}{|c|}{ Soluble cations (meq/L) } \\
\hline $\mathrm{Ca}^{++}$ & 0.92 \\
\hline $\mathrm{Mg}^{++}$ & 0.61 \\
\hline $\mathrm{K}^{+}$ & 1.48 \\
\hline $\mathrm{Na}^{+}$ & 0.21 \\
\hline \multicolumn{2}{|c|}{ Soluble anions (meq/L) } \\
\hline $\mathrm{CO}_{3}$ & - \\
\hline $\mathrm{HCO}_{3}^{-}$ & 1.88 \\
\hline $\mathrm{Cl}^{-}$ & 0.78 \\
\hline $\mathrm{SO}_{4}=$ & 0.56 \\
\hline Total-N (ppm) & 294 \\
\hline Organic-C (\%) & 0.23 \\
\hline Organic matter (\%) & 0.39 \\
\hline
\end{tabular}

Maize plants were uprooted after 80 days of planting to evaluate some growth aspects and $\mathrm{N}$ content of plant tissues. Afterwards, the plants were harvested and the grains and stalk yield were recorded for each plot. In addition, ten plants were randomly sampled from each treatment to assay some yield components.

The collected data were statistically analyzed according to Snedecor and Cochran (1980), treatment means compared by the LSD at $5 \%$ level of probability.

\section{Inoculant of rhizobacteria}

Tested pure cultures of Paenibacillus polymyxa and Serratia sp. $\left(1 \times 10^{9} \mathrm{CFU} / \mathrm{g}\right)$, local isolates were prepared as a solid inoculants via the injection of two bacterial cultures into gamma sterilized carrier (polyethylene bags contained vermiculite supplemented with $10 \%$ Irish peat) to satisfy $60 \%$ of the maximal water holding capacity. Inoculation of maize grains was done using Arabic gum as adhesive materials at rates of $600 \mathrm{~g}$ inoculant $/ 12$ Kg grains.

\section{Analytical Methods}

\section{Soil}

Mechanical and chemical analysis of the representative samples of experimental soil were executed according to Piper (1950) and Page et al (1982).

\section{Plant materials}

- Root surface area was measured by the titration method as described by Carley and Watson (1966).

- Leaf area was measured with a portable leaf Area Meter.

- The oven dried plants were grained and digested using mixture of $\mathrm{HClO}_{4}$ and $\mathrm{H}_{2} \mathrm{SO}_{4}$ at ration of $1: 1$, and then the nitrogen concentration in digested solution was determined by MacroKjeldahl (Jackson, 1973).

- Crude protein in grains and stalks of maize was calculated by multiplying of $\mathrm{N}$ concentration by 6.25 .

\section{Compost and raw materials}

- Physical properties were determined according to Iglesias-Jimenez and PerezGarcia (1989) and Culley (1993).

- Chemical and microbiological characteristics were measured according to Page et al (1982).

- Seed germination test was assayed using cress seeds (Lepidium staivum L., local varity) and barley (Hordeum vulgare, cv . Giza 132) seeds to evaluate compost maturity (Zucconi et al 1981).

- $\mathrm{E}_{4} / \mathrm{E}_{6}$ ratio (Extinction coefficient) was measured at 465 and $665 \mathrm{~nm}$ wavelengths in aqueous and alkaline extract of produced compost as described by Page et al (1982).

- $\mathrm{pH}$ under anaerobic conditions at $55^{\circ} \mathrm{C}$ as a maturity test was done according to Jann et al (1959).

- $\mathrm{C} / \mathrm{N}$ ratio in initial composted materials was calculated by the general formula for mix of materials for composting as descried by 
Rynk (1992), then the criterion regarding the $\mathrm{C} / \mathrm{N}$ ratio at starting and elapsing of composting process was calculated as described by Morel et al (1985) as follows:

(Final C/N)/(Initial C/N)

- $\mathrm{CO}_{2}$ evolution was measured according to Wu and Ma (2001).

- CEC (cations exchangeable capacity) was determined according to Harada and Inoko (1980).

\section{RESULTS AND DISCUSSION}

\section{Characteristics and some maturity/stability} indices of enriched compost

The utilization of different characteristics of composted materials and its maturity/stability indices can give a comprehensive figure about the degree of organic matter decomposition and potential phytotoxicity caused by insufficient composting. These practices may be the major determinates of the successful and safe using of composts in agriculture and horticulture production (Bernal et al 1998 and $\mathrm{Wu} \& \mathrm{Ma}, 2001)$. Therefore, the physio-chemical and microbiological characteristics as well as some indices of maturity and stability of enriched compost were measured after elapsing of composting process.

\section{a- Physio-chemical and microbiological char- acteristics}

From peruse of the results presented in Table (3), it is apparent that the physical properties of enriched compost exhibited a relevant values and it's in acceptable limits with regard of the composts prepared from such used raw materials. The reasonable values of water holding capacity and bulk density (292\% and $518 \mathrm{Kg} / \mathrm{m}^{3}$, respectively) may be indicative for incidence of organic materials degradation, whereas, the increasing of bulk density indicates the reduction of the volume of raw materials as a result of decomposition processing (Rynk, 1992). Such physical properties may provide a primary indication about materials degradation, transportation, handling and its application (Abdel-Wahab, 1999). Many investigators recommended that the final composted materials should have a desired physical properties are usually dark brown to black, uniform particle size, unrecogniza- ble original materials, relatively porous, not compacted or hard and earthy odor (Rynk, 1992).

Table 3. Characteristics of enriched compost after elapsing of composting process ( 3 months)

\begin{tabular}{|c|c|c|}
\hline \multicolumn{2}{|c|}{ Character } & \multirow[t]{2}{*}{ Value } \\
\hline Physical & & \\
\hline Color & & Dark brown \\
\hline Moisture content & (\%) & 27.00 \\
\hline Water holding capacity & $(\%)$ & 278.00 \\
\hline Bulk density & $\left(\mathrm{Kg} / \mathrm{m}^{3}\right)$ & 518.00 \\
\hline \multicolumn{3}{|l|}{ Chemical } \\
\hline $\mathrm{pH}$ & & 7.28 \\
\hline EC & $(\mathrm{dS} / \mathrm{m})$ & 3.65 \\
\hline Organic-C & $(\%)$ & 21.95 \\
\hline Total-N & (\%) & 1.72 \\
\hline Organic matter & $(\%)$ & 37.70 \\
\hline Total-P & $(\%)$ & 1.08 \\
\hline Total-K & (\%) & 1.32 \\
\hline $\mathrm{N}-\mathrm{NH}_{4}^{+}$ & (ppm) & 74.30 \\
\hline $\mathrm{N}-\mathrm{NO}_{3}^{-}$ & (ppm) & 199.30 \\
\hline Available-P & (ppm) & 286.30 \\
\hline Available-K & (ppm) & 453.00 \\
\hline DTPA-extractable-Fe & (ppm) & 295.40 \\
\hline DTPA-extractable-Mn & (ppm) & 76.90 \\
\hline DTPA-extractable-Zn & (ppm) & 85.70 \\
\hline DTPA-extractable-Cu & $(\mathrm{ppm})$ & 8.30 \\
\hline \multicolumn{3}{|l|}{ Microbiological } \\
\hline Count of bacteria & $(\mathrm{CFU} / \mathrm{g})$ & $9.3 \times 10^{7}$ \\
\hline Count of fungi & $(\mathrm{CFU} / \mathrm{g})$ & $1.8 \times 10^{6}$ \\
\hline Count of actinomycets & $(\mathrm{CFU} / \mathrm{g})$ & $1.2 \times 10^{7}$ \\
\hline Count of PDB* & $(\mathrm{CFU} / \mathrm{g})$ & $8.9 \times 10^{6}$ \\
\hline Dehydrogenase activity & $\begin{array}{l}(\mathrm{mg} \\
\left.\mathrm{TPF}^{* *} / 100 \mathrm{~g}\right)\end{array}$ & 173.80 \\
\hline Nitrogenase activity & $\begin{array}{l}\text { (n mol } \\
\left.\mathrm{C}_{2} \mathrm{H}_{4} \backslash \mathrm{g} \backslash \mathrm{h}\right) \\
\end{array}$ & 68.80 \\
\hline
\end{tabular}

* $=$ Phosphate dissolving bacteria

${ }^{* *}=$ Trichloro-Phenyl-Formazan.

Concerning the chemical properties of enriched compost, data in Table (3) revealed that $\mathrm{pH}$ value nearly neutral (7.28) referring to occur the degradation and mineralization of organic materials (Bentio et al 2003).

The relatively high EC value $(3.65 \mathrm{dS} / \mathrm{m})$ may be due to release the soluble salts and soluble organic compounds as consequence to mineralization of composted materials and applied amendments. However, values of $\mathrm{pH}$ and $\mathrm{EC}$ are in ac- 
ceptable range regarding to compost utilization (Abdel-Wahab and Ahmed, 2003).

Enriched compost has appreciable content of macro and micronutrients indicating that this product has a valuable grade as organic fertilizer. Additionally, the prepared compost contains humified organic compounds (humic substances), which acting to maintain these nutrients in available forms, particularly phosphorus and micronutrients (Manna et al 2003). Moreover, the enriched compost contain the important group of beneficial microorganisms, which acting likewise the plant growth promoting rhizobacteria, which have ability to increase the nutrients availability in the rhizosphere and promote it's uptake by plants (Mantelin and Touraine, 2004).

With respect to microbiological traits of enriched compost, data in Table (3) exerted that this compost possess a valuable biotic strength, which reflected by the great numbers of the main groups of microorganisms and confirmed by the high activity of distinct groups, as expressed by the high value of nitrogenase activity $(68.8 \mathrm{n} \mathrm{mol} / \mathrm{g} / \mathrm{h})$ and count of phosphate dissolving bacteria $\left(8.9 \times 10^{6}\right.$ $\mathrm{CFU} / \mathrm{g}$ ). These results indicating that such enrich compost contains a diverse microbial communities which they have a plant growth promoting properties beside the ability of composted materials to provide these rhizobacteria with the enrich niche, which acting to maintain their survival and activity (Alvarez et al 1995). Additionally, the microbial activity in the enriched compost can play a key role in suppressing of soil born diseases (Abbasi et al 2002 and HoitiniK \& Changa, 2004).

\section{b- Some maturity indices}

The successful utilities of compost for agricultural process are critically depending on maturity/stability degree. Some maturity/stability indices of enriched compost were presented in Table (4). From the visual inspection of enriched compost samples, it is clear that their color was dark brown and their structure were mixture of fine and medium crumble size particles. The dark brown is a common color, which distinguishes the mature composted materials (Iglesias-Jimenez and Perez-Gracia, 1989).

$\mathrm{C} / \mathrm{N}$ ratio at final of composting process reached to 12.76 , nearly to acceptable level for mature compost $(\mathrm{C} / \mathrm{N}$ ratio $<12$ indicates a good degree of maturity as reported by IglesiasJimenez and Perez-Garcia, 1992). Indeed, under Egyptian conditions (arid and semiarid climate) $\mathrm{C} / \mathrm{N}$ ratio even which up to 20 (as reported by Ma- thur et al, 1993, to be the limit for bio-stable or mature compost) considered reasonable to make the organic matter is relatively recalcitrant against the rapid oxidation, which prevalent in Egyptian soils, particularly in desert regions (Abdel-Malek, 19971 and Abdel-Wahab et al 2006). In addition, the quotient of final $\mathrm{C} / \mathrm{N}$ ratio/initial ratio was very low (0.43) indicating that addition of this compost to soil not induce the immobilization of mineral-N (Van-Heerden et al 2002).

Enriched compost exhibited high CEC value $(112.70 \mathrm{c} \mathrm{mol} / \mathrm{Kg})$, which greatly exceeded similar values described as a minimum values for city refuse compost to be considered sufficiently mature (60 and $67 \mathrm{c} \mathrm{mol} / \mathrm{Kg}$, which suggested by IglesiasJimenez and Perez-Gracia (1992)). However, Bernal et al (1998) reported that immature composts and even raw materials can reach the above-mentioned values of CEC. Regarding the ratio of $\mathrm{CEC}$ /organic-C as maturity index for enriched compost, it recorded a high value $(5.15 \mathrm{C}$ $\mathrm{mol} / \mathrm{Kg}$ ) as compared to well humified composts prepared from wide range of raw materials (Iglesias-Jimenez \& Perez-Gracia, 1992; Bernal et al 1998 and Manna et al 2003).

A remixing of composted materials after elapsing of composting process under anaerobic conditions and incubated at $55^{\circ} \mathrm{C}$, for $24 \mathrm{~h}$ well cause a resurgence in fermentation if the compost is immature leading to decrease the $\mathrm{pH}$ value toward acidity as a consequence of the accumulation of organic acids (Jann et al 1959 and Iglesias-Jimenez \& Perez-Gracia, 1989). Practice of this test with enriched compost exerted that their samples are still neutral or toward the alkalinity (7.11) indicating that this product may be considered mature and haven't phytotoxicity potential which may caused as function of the organic acids existence during the fermentation of immature compost.

The ratio of optical densities of humic substances at 465 and $665 \mathrm{~nm}\left(\mathrm{E}_{4} / \mathrm{E}_{6}\right)$ was along considered to reflect the degree of condensation of the aromatic nucleus of humus or it's maturity. $E_{4} / E_{6}$ of the enriched compost was moderate in aqueous extract (3.98), while it is relatively low in the alkaline one (1.99) indicating that the enriched compost contains polycondensed humic substances due to the progress of humification process (Mathur et al 1993). In this respect, Iglesias-Jimenez and Perez-Gracia (1989) indicated that alkaline extract of the compost was brown-black color and their hue is light at the beginning of composting and tends to darken as compost mature. 
Data in Table (4) revealed that thermophilic bacteria were greatly lesser than mesophilic one, indicating that the enriched compost may reach to acceptable degree of maturity. Indeed, thermophilic bacteria decreases in the last phase of composting process due to exhaustion of substrate and fall the temperature as the compost reaches maturity (Ryckeboer et al 2003).

Table 4. Some maturity and satiability indices of enriched compost

\begin{tabular}{|ll|}
\hline \multicolumn{1}{|c|}{ Parameter } & \multicolumn{1}{c|}{ Value } \\
\hline Color & Dark brown \\
$\mathrm{C} / \mathrm{N}$ ratio & 12.76 \\
(Final C/N)/(Initial C/N) & 0.43 \\
$\mathrm{CEC}(\mathrm{c} \mathrm{mol} / \mathrm{kg})$ & 112.70 \\
$\mathrm{CEC} /$ Organic-C & 5.15 \\
$\mathrm{pH}$ of saturated sample at $55^{\circ} \mathrm{C}$ & 7.11 \\
$\mathrm{E}_{4} / \mathrm{E}_{6}$ assay:- & \\
Aqueous extract & 3.98 \\
Alkaline extract & 1.99 \\
Bacterial count (CFU/g) & \\
Thermophilic bacteria & $3.2 \times 10^{5}$ \\
Mesophilic bacteria & $9.3 \times 10^{7}$ \\
Accumulated CO & \\
Aftevolution & \\
Aft & \\
After $2^{\text {nd }}$ day & 4.70 \\
After $3^{\text {rd }}$ day & 3.50 \\
Seed germination test (\%) & 3.90 \\
On cress seeds & \\
On barley seeds & 88.70 \\
\hline
\end{tabular}

${ }^{*}=\mathrm{mg} \mathrm{CO}_{2} / \mathrm{g} \mathrm{dw} /$ day.

As a result of the total $\mathrm{CO}_{2}$-evolution for 3 days to evaluate the stability of enriched compost (Table, 4), it is clear that the overall $\mathrm{CO}_{2}$-evolution rate was relatively low and exhibited no linear peak, which reflected a reasonable degree of stability. These results are in accordance with $\mathbf{W u}$ et al (2000); Wu and Ma (2001) and Benito et al (2003), who reported that the $\mathrm{CO}_{2}$-evolution rate remained nearly stable during the curing phase of composting. In controversy, Wang et al (2004) suggested that compost must be stabilized to reach at least $1.0 \mathrm{mg} \mathrm{CO} 2 \mathrm{C} / \mathrm{g} / \mathrm{dw} /$ day. However, excessively stabilized charred or pyrolyzed particles in compost don't support an adequate microbial biomass to exhibit desired microbial functions such as biological control and nutrients sequestration in rhizosphere particularly under arid and semiarid conditions (Hoitink \& Boehm, 1999 and Abdel-Wahab et al 2006).
The relative germination test of cress seeds is the most sensitive parameter used to evaluate the phytotoxicity and degree of maturity of compost (Zucconi et al 1981). Data in Table (4) revealed that the value of germination test for cress and barley seeds were 88.7 and $91.5 \%$, respectively, where greatly exceeded $50 \%$ as germination index suggested by Zucconi et al (1981). These results indicated that the enriched compost has a valuable degree of maturity which may be attributed to greatly diminish the phytotoxic compounds, which exposed to degradation along the composting process giving mature compost, which could safely be used with cultivated plants (Bernal et al 1998).

It could be concluded that, to reach a profound concept about a maturity and stability of compost it should be practice more than parameter, which encompassing their physical, chemical and biological properties to ensure the safe manuring for cultivated soils without occurring any phytotoxicity, taking in account the potential loosing of organic matter, which causing under dry climate condition as well as maintaining the biological quality of composts.

Effect of enriched compost, rhizobacteria and $\mathrm{N}$-fertilization on the maize

\section{a- Growth aspects after 80 days of planting}

The response of maize plants to bio-organic fertilization and different levels of $\mathrm{N}$-fertilizer was represented by some growth aspects namely, plant height, dry matter, leaf area, root surface area and $\mathrm{N}$-content of plant tissues during the two consecutive seasons (Tables 5 and $\mathbf{6}$ ).

The main effect of the different fertilization approaches revealed that growth aspects of maize plants were extremely affected by the mineral fertilization rather than organic and/or bio one. Irrespective of bio-organic treatments, increasing of applied dose of $\mathrm{N}$-fertilizer resulted in gradual significant increases in all investigated traits among the two studied seasons. Obviously, the highest values of plant vigor of maize were attained as a result of addition of the highest dose of $\mathrm{N}$-fertilizer $(120 \mathrm{Kg} / \mathrm{fed})$. For instance, addition of $120 \mathrm{Kg}$ $\mathrm{N} /$ fed to maize plants results in $38.55 \mathrm{~g} /$ plant root dry matter with 25-62 $\mathrm{ml} \mathrm{NaOH} /$ plant, surface area, leading to originate high dry matter of shoot reached to $105.91 \mathrm{~g} /$ plant, which it accumulated $2254.1 \mathrm{mg} \mathrm{N} /$ plant in their tissues during the first season (2005). The corresponding values obtained at the second season (2006) were $36.66 \mathrm{~g} / \mathrm{plant}$ with $27.24 \mathrm{ml} \mathrm{NaOH} /$ plant leading to $108.36 \mathrm{~g} /$ plant which accumulated $2393.3 \mathrm{mg} /$ plant. 
Concerning the main effect of organic and/or biofertilization, data exhibited that the topdressing with enriched compost at rate of 5 ton/fed was the distinct practice for increasing the plant vigor of maize as compared to rhizobacteria as sole application or the control treatment (without organic or bio-fertilization). However, the synergistic effect between organic manuring and rhizobacteria achieved the highest values of plant vigor and $\mathrm{N}$ content in spite of the means differences was not significant in most cases in comparison with solely organic manuring.

In respect of the interaction between the different strategies of fertilization, data in the Tables (5) and (6) showed that the plant vigor and $\mathrm{N}$-contents was superior as a result of the integrated fertilization strategy, particularly when corn plants received $120 \mathrm{Kg} \mathrm{N} / \mathrm{fed}$ in combination with 5 ton/fed enriched compost and rhizobacteria. This trend was true at the two investigation seasons. Indeed, these results exhibited that the promotive effect of rhizobacteria on the plant vigor was only positive in case of their synergistic effect with organic and mineral fertilization. This finding may be emphasized the essential role of composted and humified organic substances for providing the maize rhizosphere with enriched niche, which acting to enhance the survival and activity of their indigenously habitat microorganisms and the added rhizobacteria resulting in promoting of the plant growth. The positive effects of synergy between organic materials and rhizobacteria is to magnify their promotive action on the plants grown in the newly reclaimed soils that proved by many investigators (AbdelWahab et al 1999; El-Ghadban et al 2003; Abdel-Wahab et al 2006 and Abo El-Soud et al 2006). Additionally, growth promotion by rhizobacteria may resulted from several mechanisms such as producing of phytohormones, siderophores, increasing of nutrients availability through nitrogen fixation and phosphate solubilization as well as bioprotection of cultivated plants against phytopathogens (Kloepper, 1993; Glick et al 1999; Vessey, 2003 and Van-Loon and Bakker, 2003).

\section{b- Yield and its attributes}

Influence of bio-organic amending and graded levels of $\mathrm{N}$-fertilization on the maize yield and its attributes for two consecutive seasons are represented in Tables (7) and (8). Generally, data revealed that maize yield and its components appeared high response to mineral fertilization rather than organic or bio-organic one as consistent with a previous trend obtained at vegetative growth stage. Regardless of bio-organic treatments, increasing of applied $\mathrm{N}$-fertilizer dose resulted in gradually significant increases in the maize yield and its attributes. For instance, addition of $\mathrm{N}$ fertilizer at levels of 60,90 and $120 \mathrm{Kg} \mathrm{N} / \mathrm{fed}$ led to increase the grain yield by $103.70,141.12$ and $174.77 \%$, respectively over the control treatment (30 Kg N/fed) for the first season (2005). Same trend was obtained in the second season (2006) and the corresponding percentage increases in the grain yield reached to $144.79,182.29$ and $217.71 \%$, respectively.

In respect of the main effect of bio- and organic treatments, data exerted that enhancement of maize yield (grain and stalk weight) and its attributes, namely hundred grains weight, ear diameter, ear length and crude protein of yield was occurred in the plots, which topdressed with enriched compost, singularly or in conjugation with rhizobacteria. However, using of rhizobacteria inoculation as a sole strategy did not exerted any positive effects on maize yield or any of its attributes. In other words, topdressed of soil with enriched compost led to increase the grain yield of maize by $19.70 \%$ and this percentage increase raised to $25.76 \%$ when organic manuring conjugated with rhizobacteria during the first season. The corresponding values obtained in the second season were 21.50 and $29.50 \%$, respectively. The failing of rhizobacteria to achieve any positive effect on maize, when they applied solely may be elucidated by the necessity of heterotrophic bacteria (including the used rhizobacteria) to organic substances for their proliferation and survival, particularly under severe conditions of desert soil, which it is commonly very poor in their fertility and consequently in its biological traits (Abdel-Wahab et al 2003). Additionally, the existence of enriched compost solely or in combination with rhizobacteria exhibited a salient promotion for the maize yield and its attributes, which may be explained by the key role of different humic substances, which acting increasing the productivity and quality of maize. Moreover, compost had a vital role in improvement of physical and chemical prosperities of soil as well as reducing the incidence of plant diseases (Hoitink and Boehm, 1999). So far, the efficiency of $\mathrm{N}$ fertilization was further improved due to application of enriched compost as it provided a better environment conditions with plenteous growth, more suitable for survival and growth of both indigenous and introduced rhizobacteria, beside its role in increasing the level of supply of nutritional elements 
Table 5. Effect of bio-organic fertilization on growth aspects of maize plants under graded $\mathrm{N}$-levels after 80 days of planting ( $1^{\text {st }}$ season, 2005)

\begin{tabular}{|c|c|c|c|c|c|c|c|}
\hline Treatments & $\begin{array}{l}\text { Plant } \\
\text { height } \\
(\mathrm{cm})\end{array}$ & $\begin{array}{l}\text { Shoot } \\
\text { D.wt } \\
\text { (g/plant) }\end{array}$ & $\begin{array}{c}\text { Root } \\
\text { D.wt } \\
\text { (g/plant) }\end{array}$ & $\begin{array}{l}\text { Leaf area } \\
\text { ( } \mathrm{cm}^{2} / \\
\text { plant })\end{array}$ & $\begin{array}{l}\text { Root } \\
\text { surface } \\
\text { area } \\
\text { (ml } \\
\mathrm{NaOH})\end{array}$ & $\begin{array}{l}\text { Shoot-N } \\
\text { content } \\
\text { (mg/plant) }\end{array}$ & $\begin{array}{c}\text { Root-N } \\
\text { content } \\
\text { (mg/plant) }\end{array}$ \\
\hline & \multicolumn{7}{|c|}{ Control (without bio-organic) $\left(\mathrm{BO}_{1}\right)$} \\
\hline $30 \mathrm{Kg} \mathrm{N} / \mathrm{fed}\left(\mathrm{N}_{1}\right)$ & 86.90 & 37.15 & 17.33 & 331.80 & 19.60 & 379.50 & 98.70 \\
\hline $60 \mathrm{Kg} \mathrm{N} / \mathrm{fed}\left(\mathrm{N}_{2}\right)$ & 157.80 & 57.33 & 21.69 & 395.63 & 20.87 & 752.10 & 165.80 \\
\hline $90 \mathrm{Kg} \mathrm{N} / \mathrm{fed}\left(\mathrm{N}_{3}\right)$ & 207.7 & 86.13 & 25.90 & 430.87 & 22.07 & 1448.20 & 211.40 \\
\hline $120 \mathrm{Kg} \mathrm{N} / \mathrm{fed}\left(\mathrm{N}_{4}\right)$ & 226.70 & 98.14 & 35.20 & 486.13 & 23.33 & 2030.70 & 286.90 \\
\hline \multirow[t]{2}{*}{ Overall means } & 169.70 & 69.69 & 25.04 & 397.61 & 21.47 & 1152.60 & 190.70 \\
\hline & \multicolumn{7}{|c|}{5 ton compost/fed $\left(\mathrm{BO}_{2}\right)$} \\
\hline $30 \mathrm{Kg} \mathrm{N} / \mathrm{fed}\left(\mathrm{N}_{1}\right)$ & 99.10 & 43.26 & 20.27 & 353.43 & 21.10 & 689.50 & 145.60 \\
\hline $60 \mathrm{Kg} \mathrm{N} / \mathrm{fed}\left(\mathrm{N}_{2}\right)$ & 180.50 & 71.22 & 25.39 & 402.63 & 22.53 & 1022.30 & 211.40 \\
\hline $90 \mathrm{Kg} \mathrm{N} / \mathrm{fed}\left(\mathrm{N}_{3}\right)$ & 219.80 & 97.38 & 29.49 & 445.47 & 24.77 & 1692.8 & 255.50 \\
\hline $120 \mathrm{Kg} \mathrm{N} / \mathrm{fed}\left(\mathrm{N}_{4}\right)$ & 242.20 & 106.38 & 39.76 & 499.20 & 27.27 & 2321.30 & 343.80 \\
\hline \multirow[t]{2}{*}{ Overall means } & 185.40 & 79.56 & 28.73 & 425.31 & 23.92 & 1431.50 & 239.07 \\
\hline & \multicolumn{7}{|c|}{ Inoculation with rhizobacteria $\left(\mathrm{BO}_{3}\right)$} \\
\hline $30 \mathrm{Kg} \mathrm{N} / \mathrm{fed}\left(\mathrm{N}_{1}\right)$ & 90.70 & 39.54 & 18.12 & 340.20 & 20.17 & 391.10 & 103.10 \\
\hline $60 \mathrm{Kg} \mathrm{N} / \mathrm{fed}\left(\mathrm{N}_{2}\right)$ & 158.20 & 61.98 & 22.74 & 363.63 & 21.40 & 767.10 & 170.50 \\
\hline $90 \mathrm{Kg} \mathrm{N} / \mathrm{fed}\left(\mathrm{N}_{3}\right)$ & 213.80 & 90.95 & 26.43 & 440.00 & 21.93 & 1477.9 & 214.50 \\
\hline $120 \mathrm{Kg} \mathrm{N} / \mathrm{fed}\left(\mathrm{N}_{4}\right)$ & 228.80 & 99.28 & 38.09 & 481.47 & 23.77 & 2066.10 & 306.70 \\
\hline \multirow[t]{2}{*}{ Overall means } & 172.90 & 72.94 & 26.35 & 406.33 & 21.82 & 1175.60 & 198.70 \\
\hline & \multicolumn{7}{|c|}{ Compost + rhizobacteria $\left(\mathrm{BO}_{4}\right)$} \\
\hline $30 \mathrm{Kg} \mathrm{N} / \mathrm{fed}\left(\mathrm{N}_{1}\right)$ & 99.80 & 48.19 & 21.95 & 360.37 & 21.50 & 694.30 & 152.50 \\
\hline $60 \mathrm{Kg} \mathrm{N} / \mathrm{fed}\left(\mathrm{N}_{2}\right)$ & 176.70 & 78.57 & 25.64 & 419.40 & 23.10 & 1103.10 & 212.70 \\
\hline $90 \mathrm{Kg} \mathrm{N} / \mathrm{fed}\left(\mathrm{N}_{3}\right)$ & 220.30 & 100.76 & 32.14 & 471.93 & 25.50 & 1864.80 & 270.30 \\
\hline $120 \mathrm{Kg} \mathrm{N} / \mathrm{fed}\left(\mathrm{N}_{4}\right)$ & 244.50 & 119.85 & 41.16 & 506.17 & 28.10 & 2598.20 & 375.60 \\
\hline \multirow[t]{2}{*}{ Overall means } & 185.30 & 86.84 & 30.22 & 439.47 & 24.55 & 1565.10 & 252.80 \\
\hline & \multicolumn{7}{|c|}{ Overall means of $\mathrm{N}$-fertilizer levels } \\
\hline $\mathrm{N}_{1}$ & 94.10 & 42.03 & 19.42 & 346.58 & 20.59 & 583.60 & 125.00 \\
\hline $\mathrm{N}_{2}$ & 168.30 & 67.27 & 23.86 & 386.33 & 21.98 & 911.20 & 190.10 \\
\hline $\mathrm{N}_{3}$ & 215.40 & 93.81 & 28.50 & 447.07 & 23.57 & 1620.90 & 237.90 \\
\hline $\mathrm{N}_{4}$ & 235.50 & 105.91 & 38.55 & 488.74 & 25.62 & 2254.10 & 328.20 \\
\hline \multicolumn{8}{|l|}{ LSD $_{0.05:}$} \\
\hline $\mathrm{N}$ & 6.85 & 4.62 & 1.90 & 27.80 & 1.06 & 159.60 & 24.69 \\
\hline $\mathrm{BO}$ & 6.85 & 4.62 & 1.90 & 27.80 & 1.06 & 159.60 & 24.69 \\
\hline $\mathrm{N} \times \mathrm{BO}$ & 13.98 & 7.56 & 2.75 & 55.75 & 1.36 & 245.60 & 39.49 \\
\hline
\end{tabular}


Table 6. Effect of bio-organic fertilization on growth aspects of maize plants under graded $\mathrm{N}$-levels after 80 days of planting ( $2^{\text {nd }}$ season, 2006)

\begin{tabular}{|c|c|c|c|c|c|c|c|}
\hline Treatments & $\begin{array}{c}\text { Plant } \\
\text { height } \\
(\mathrm{cm})\end{array}$ & $\begin{array}{l}\text { Shoot } \\
\text { D.wt } \\
\text { (g/plant) }\end{array}$ & $\begin{array}{c}\text { Root } \\
\text { D.wt } \\
\text { (g/plant) }\end{array}$ & $\begin{array}{l}\text { Leaf area } \\
\text { (cm²/plant) }\end{array}$ & $\begin{array}{c}\text { Root } \\
\text { surface } \\
\text { area }(\mathrm{ml} \\
\mathrm{NaOH})\end{array}$ & $\begin{array}{l}\text { Shoot-N } \\
\text { content } \\
\text { (mg/plant) }\end{array}$ & $\begin{array}{c}\text { Root-N } \\
\text { content } \\
\text { (mg/plant) }\end{array}$ \\
\hline & & \multicolumn{6}{|c|}{ Control (without bio-organic) $\left(\mathrm{BO}_{1}\right)$} \\
\hline $30 \mathrm{Kg} \mathrm{N} / \mathrm{fed}\left(\mathrm{N}_{1}\right)$ & 93.00 & 39.21 & 18.31 & 335.21 & 20.90 & 390.40 & 110.90 \\
\hline $60 \mathrm{Kg} \mathrm{N} / \mathrm{fed}\left(\mathrm{N}_{2}\right)$ & 162.00 & 67.00 & 22.93 & 362.40 & 22.32 & 897.50 & 182.40 \\
\hline $90 \mathrm{Kg} \mathrm{N} / \mathrm{fed}\left(\mathrm{N}_{3}\right)$ & 214.00 & 90.33 & 26.51 & 439.28 & 23.41 & 1552.40 & 221.50 \\
\hline $120 \mathrm{Kg} \mathrm{N} / \mathrm{fed}\left(\mathrm{N}_{4}\right)$ & 231.00 & 104.23 & 35.86 & 479.81 & 24.96 & 2153.30 & 298.70 \\
\hline \multirow[t]{2}{*}{ Overall means } & 175.00 & 75.20 & 25.90 & 404.18 & 22.89 & 1248.40 & 203.40 \\
\hline & & \multicolumn{6}{|c|}{5 ton compost/fed $\left(\mathrm{BO}_{2}\right)$} \\
\hline $30 \mathrm{Kg} \mathrm{N} / \mathrm{fed}\left(\mathrm{N}_{1}\right)$ & 103.00 & 43.21 & 20.21 & 354.58 & 21.95 & 466.70 & 151.10 \\
\hline $60 \mathrm{Kg} \mathrm{N} / \mathrm{fed}\left(\mathrm{N}_{2}\right)$ & 187.00 & 69.41 & 24.94 & 415.72 & 23.84 & 930.10 & 211.20 \\
\hline $90 \mathrm{Kg} \mathrm{N} / \mathrm{fed}\left(\mathrm{N}_{3}\right)$ & 223.00 & 98.12 & 29.53 & 453.34 & 26.56 & 1811.70 & 260.60 \\
\hline $120 \mathrm{Kg} \mathrm{N} / \mathrm{fed}\left(\mathrm{N}_{4}\right)$ & 248.00 & 108.21 & 36.13 & 509.30 & 28.41 & 2415.70 & 360.50 \\
\hline \multirow[t]{2}{*}{ Overall means } & 190.30 & 79.74 & 27.70 & 433.24 & 25.19 & 1406.00 & 245.90 \\
\hline & & \multicolumn{6}{|c|}{ Inoculation with rhizobacteria $\left(\mathrm{BO}_{3}\right)$} \\
\hline $30 \mathrm{Kg} \mathrm{N} / \mathrm{fed}\left(\mathrm{N}_{1}\right)$ & 96.00 & 40.51 & 18.46 & 339.90 & 20.23 & 405.80 & 121.20 \\
\hline $60 \mathrm{Kg} \mathrm{N} / \mathrm{fed}\left(\mathrm{N}_{2}\right)$ & 165.00 & 68.23 & 22.74 & 365.47 & 22.84 & 885.70 & 184.30 \\
\hline $90 \mathrm{Kg} \mathrm{N} / \mathrm{fed}\left(\mathrm{N}_{3}\right)$ & 218.00 & 93.01 & 26.43 & 442.11 & 23.12 & 1662.80 & 229.50 \\
\hline $120 \mathrm{Kg} \mathrm{N} / \mathrm{fed}\left(\mathrm{N}_{4}\right)$ & 231.00 & 101.80 & 34.93 & 469.82 & 25.64 & 2113.20 & 311.60 \\
\hline \multirow[t]{2}{*}{ Overall means } & 178.3 & 75.89 & 25.64 & 404.33 & 22.96 & 1266.90 & 211.50 \\
\hline & & \multicolumn{6}{|c|}{ Compost + rhizobacteria $\left(\mathrm{BO}_{3}\right)$} \\
\hline $30 \mathrm{Kg} \mathrm{N} / \mathrm{fed}\left(\mathrm{N}_{1}\right)$ & 109.00 & 49.21 & 21.28 & 353.37 & 22.50 & 576.20 & 161.00 \\
\hline $60 \mathrm{Kg} \mathrm{N} / \mathrm{fed}\left(\mathrm{N}_{2}\right)$ & 197.00 & 75.34 & 26.91 & 420.10 & 24.30 & 1267.40 & 224.70 \\
\hline $90 \mathrm{Kg} \mathrm{N} / \mathrm{fed}\left(\mathrm{N}_{3}\right)$ & 234.00 & 101.23 & 31.75 & 488.77 & 27.50 & 1973.70 & 282.70 \\
\hline $120 \mathrm{Kg} \mathrm{N} / \mathrm{fed}\left(\mathrm{N}_{4}\right)$ & 251.00 & 119.19 & 39.72 & 514.70 & 29.96 & 2891.10 & 391.30 \\
\hline \multirow[t]{2}{*}{ Overall means } & 197.80 & 86.24 & 29.92 & 444.24 & 26.07 & 1677.10 & 264.91 \\
\hline & & \multicolumn{6}{|c|}{ Overall means of $\mathrm{N}$-fertilizer levels } \\
\hline $\mathrm{N}_{1}$ & 100.30 & 43.04 & 19.61 & 345.77 & 21.40 & 459.70 & 136.10 \\
\hline $\mathrm{N}_{2}$ & 177.80 & 70.00 & 24.38 & 390.92 & 23.33 & 995.20 & 200.60 \\
\hline $\mathrm{N}_{3}$ & 222.30 & 95.67 & 28.56 & 455.88 & 25.15 & 1750.20 & 248.60 \\
\hline $\mathrm{N}_{4}$ & 240.30 & 108.36 & 36.66 & 493.41 & 27.24 & 2393.30 & 340.40 \\
\hline \multicolumn{8}{|l|}{ LSD $_{0.05:}$} \\
\hline $\mathrm{N}$ & 6.92 & 4.81 & 1.94 & 27.54 & 1.18 & 163.31 & 25.13 \\
\hline BO & 6.92 & 4.81 & 1.94 & 27.54 & 1.18 & 163.31 & 25.13 \\
\hline $\mathrm{N} \times \mathrm{BO}$ & 14.19 & 8.31 & 3.01 & 56.18 & 1.59 & 248.61 & 40.25 \\
\hline
\end{tabular}


Table 7. Response of maize yield and its components to bio-organic fertilization as influenced by graded N-levels ( $1^{\text {st }}$ season, 2005)

\begin{tabular}{|c|c|c|c|c|c|c|c|}
\hline Treatments & $\begin{array}{l}\text { Grain } \\
\text { yield } \\
\text { (ton/fed) }\end{array}$ & $\begin{array}{l}\text { Stalk yield } \\
\text { (ton/fed) }\end{array}$ & $\begin{array}{l}\text { Hundred } \\
\text { grains } \\
\text { weight } \\
\text { (gm) }\end{array}$ & $\begin{array}{l}\text { Ear length } \\
\quad(\mathrm{cm})\end{array}$ & $\begin{array}{l}\text { Ear } \\
\text { diameter } \\
(\mathrm{cm})\end{array}$ & $\begin{array}{l}\text { Crude } \\
\text { protein of } \\
\text { grains (\%) }\end{array}$ & $\begin{array}{l}\text { Crude } \\
\text { protein of } \\
\text { stalk (\%) }\end{array}$ \\
\hline & \multicolumn{7}{|c|}{ Control (without bio-organic) $\left(\mathrm{BO}_{1}\right)$} \\
\hline $30 \mathrm{Kg} \mathrm{N} / \mathrm{fed}\left(\mathrm{N}_{1}\right)$ & 0.94 & 1.88 & 25.26 & 13.30 & 4.20 & 8.75 & 3.56 \\
\hline $60 \mathrm{Kg} \mathrm{N} / \mathrm{fed}\left(\mathrm{N}_{2}\right)$ & 2.03 & 3.60 & 28.66 & 17.10 & 4.80 & 9.20 & 4.14 \\
\hline $90 \mathrm{Kg} \mathrm{N} / \mathrm{fed} \quad\left(\mathrm{N}_{3}\right)$ & 2.28 & 3.87 & 32.74 & 18.90 & 5.10 & 10.67 & 4.43 \\
\hline $120 \mathrm{Kg} \mathrm{N} / \mathrm{fed}\left(\mathrm{N}_{4}\right)$ & 2.68 & 4.38 & 35.14 & 20.70 & 5.60 & 11.61 & 4.96 \\
\hline \multirow{2}{*}{ Overall means } & 1.98 & 3.43 & 30.45 & 17.50 & 4.90 & 10.06 & 4.27 \\
\hline & \multicolumn{7}{|c|}{5 ton compost/fed $\left(\mathrm{BO}_{2}\right)$} \\
\hline $30 \mathrm{Kg} \mathrm{N} / \mathrm{fed}\left(\mathrm{N}_{1}\right)$ & 1.19 & 2.62 & 30.59 & 14.80 & 4.80 & 9.34 & 4.15 \\
\hline $60 \mathrm{Kg} \mathrm{N} / \mathrm{fed}\left(\mathrm{N}_{2}\right)$ & 2.44 & 3.83 & 33.77 & 18.60 & 5.30 & 10.70 & 4.71 \\
\hline $90 \mathrm{Kg} \mathrm{N} / \mathrm{fed}\left(\mathrm{N}_{3}\right)$ & 2.80 & 4.33 & 36.49 & 19.80 & 5.90 & 11.82 & 5.04 \\
\hline $120 \mathrm{Kg} \mathrm{N} / \mathrm{fed}\left(\mathrm{N}_{4}\right)$ & 3.04 & 4.74 & 38.14 & 22.40 & 6.20 & 12.73 & 5.50 \\
\hline \multirow[t]{2}{*}{ Overall means } & 2.37 & 3.88 & 34.73 & 18.90 & 5.20 & 11.15 & 4.85 \\
\hline & \multicolumn{7}{|c|}{ Inoculation with rhizobacteria $\left(\mathrm{BO}_{3}\right)$} \\
\hline $30 \mathrm{Kg} \mathrm{N} / \mathrm{fed}\left(\mathrm{N}_{1}\right)$ & 0.93 & 1.74 & 26.31 & 13.40 & 4.40 & 8.91 & 3.55 \\
\hline $60 \mathrm{Kg} \mathrm{N} / \mathrm{fed}\left(\mathrm{N}_{2}\right)$ & 2.09 & 3.58 & 30.17 & 17.60 & 4.80 & 9.98 & 4.02 \\
\hline $90 \mathrm{Kg} \mathrm{N} / \mathrm{fed}\left(\mathrm{N}_{3}\right)$ & 2.37 & 3.96 & 33.11 & 19.30 & 5.40 & 10.77 & 4.39 \\
\hline $120 \mathrm{Kg} \mathrm{N} / \mathrm{fed}\left(\mathrm{N}_{4}\right)$ & 2.67 & 4.36 & 35.90 & 20.70 & 5.80 & 11.88 & 4.96 \\
\hline \multirow[t]{2}{*}{ Overall means } & 1.93 & 3.41 & 31.37 & 17.70 & 5.10 & 10.39 & 4.23 \\
\hline & \multicolumn{7}{|c|}{ Compost + rhizobacteria $\left(\mathrm{BO}_{3}\right)$} \\
\hline $30 \mathrm{Kg} \mathrm{N} / \mathrm{fed}\left(\mathrm{N}_{1}\right)$ & 1.23 & 2.76 & 31.48 & 14.90 & 4.90 & 9.67 & 4.50 \\
\hline $60 \mathrm{Kg} \mathrm{N} / \mathrm{fed}\left(\mathrm{N}_{2}\right)$ & 2.48 & 3.84 & 35.80 & 19.40 & 5.50 & 11.03 & 4.90 \\
\hline $90 \mathrm{Kg} \mathrm{N} / \mathrm{fed}\left(\mathrm{N}_{3}\right)$ & 2.85 & 4.41 & 37.88 & 21.20 & 6.00 & 12.07 & 5.06 \\
\hline $120 \mathrm{Kg} \mathrm{N} / \mathrm{fed}\left(\mathrm{N}_{4}\right)$ & 3.38 & 5.09 & 38.95 & 23.00 & 6.60 & 13.37 & 5.91 \\
\hline \multirow[t]{2}{*}{ Overall means } & 2.49 & 4.03 & 36.20 & 19.60 & 5.60 & 11.54 & 5.09 \\
\hline & \multicolumn{7}{|c|}{ Overall means of $\mathrm{N}$-fertilizer levels } \\
\hline $\mathrm{N}_{1}$ & 1.07 & 2.25 & 28.41 & 14.10 & 4.60 & 9.17 & 3.94 \\
\hline $\mathrm{N}_{2}$ & 2.18 & 3.71 & 32.27 & 18.20 & 5.10 & 10.23 & 4.44 \\
\hline $\mathrm{N}_{3}$ & 2.58 & 4.14 & 35.05 & 19.80 & 5.60 & 11.33 & 4.73 \\
\hline $\mathrm{N}_{4}$ & 2.94 & 4.65 & 37.02 & 21.70 & 6.00 & 12.40 & 5.33 \\
\hline \multicolumn{8}{|l|}{ LSD $_{0.05:}$} \\
\hline $\mathrm{N}$ & 0.26 & 0.28 & 1.76 & 1.04 & 0.31 & 0.73 & 0.42 \\
\hline $\mathrm{BO}$ & 0.26 & 0.28 & 1.76 & 1.04 & 0.31 & 0.73 & 0.42 \\
\hline $\mathrm{N} \times \mathrm{BO}$ & 0.28 & 0.56 & 3.67 & 1.45 & 0.37 & 0.97 & 0.86 \\
\hline
\end{tabular}


Table 8. Response of maize yield and its components to bio-organic fertilization as influenced by graded N-levels (2 ${ }^{\text {nd }}$ season, 2006)

\begin{tabular}{|c|c|c|c|c|c|c|c|}
\hline Treatments & $\begin{array}{l}\text { Grain } \\
\text { yield } \\
\text { (ton/fed) }\end{array}$ & $\begin{array}{c}\text { Stalk } \\
\text { yield } \\
\text { (ton/fed) }\end{array}$ & $\begin{array}{l}\text { Hundred } \\
\text { grains } \\
\text { weight } \\
\text { (gm) }\end{array}$ & $\begin{array}{l}\text { Ear } \\
\text { length } \\
(\mathrm{cm})\end{array}$ & $\begin{array}{l}\text { Ear } \\
\text { diameter } \\
(\mathrm{cm})\end{array}$ & $\begin{array}{l}\text { Crude } \\
\text { protein } \\
\text { of grains } \\
(\%)\end{array}$ & $\begin{array}{l}\text { Crude } \\
\text { protein } \\
\text { of stalk } \\
(\%)\end{array}$ \\
\hline \multicolumn{8}{|c|}{ Control (without bio-organic) $\left(\mathrm{BO}_{1}\right)$} \\
\hline $30 \mathrm{Kg} \mathrm{N} / \mathrm{fed}\left(\mathrm{N}_{1}\right)$ & 0.79 & 1.90 & 26.19 & 11.60 & 3.50 & 7.88 & 3.82 \\
\hline $60 \mathrm{Kg} \mathrm{N} / \mathrm{fed}\left(\mathrm{N}_{2}\right)$ & 2.07 & 3.71 & 28.90 & 16.00 & 4.00 & 8.97 & 4.51 \\
\hline $90 \mathrm{Kg} \mathrm{N} / \mathrm{fed}\left(\mathrm{N}_{3}\right)$ & 2.39 & 3.96 & 32.51 & 18.00 & 4.50 & 10.37 & 4.63 \\
\hline $120 \mathrm{Kg} \mathrm{N} / \mathrm{fed}\left(\mathrm{N}_{4}\right)$ & 2.77 & 4.40 & 34.61 & 19.90 & 4.90 & 11.46 & 5.02 \\
\hline Overall means & 2.00 & 3.49 & 30.55 & 16.40 & 4.30 & 9.67 & 4.50 \\
\hline \multicolumn{8}{|c|}{5 ton compost/fed $\left(\mathrm{BO}_{2}\right)$} \\
\hline $30 \mathrm{Kg} \mathrm{N} / \mathrm{fed}\left(\mathrm{N}_{1}\right)$ & 1.07 & 2.78 & 30.51 & 13.20 & 4.00 & 9.85 & 4.21 \\
\hline $60 \mathrm{Kg} \mathrm{N} / \mathrm{fed}\left(\mathrm{N}_{2}\right)$ & 2.53 & 3.95 & 33.54 & 17.80 & 4.70 & 11.00 & 4.92 \\
\hline $90 \mathrm{Kg} \mathrm{N} / \mathrm{fed}\left(\mathrm{N}_{3}\right)$ & 2.95 & 4.44 & 35.86 & 19.80 & 5.00 & 11.98 & 5.11 \\
\hline $120 \mathrm{Kg} \mathrm{N} / \mathrm{fed}\left(\mathrm{N}_{4}\right)$ & 3.18 & 4.89 & 36.98 & 21.80 & 5.50 & 12.79 & 5.74 \\
\hline Overall means & 2.43 & 4.02 & 34.28 & 18.18 & 4.79 & 11.41 & 4.88 \\
\hline \multicolumn{8}{|c|}{ Inoculation with rhizobacteria $\left(\mathrm{BO}_{3}\right)$} \\
\hline $30 \mathrm{Kg} \mathrm{N} / \mathrm{fed}\left(\mathrm{N}_{1}\right)$ & 0.80 & 2.27 & 27.00 & 12.90 & 3.60 & 8.07 & 3.76 \\
\hline $60 \mathrm{Kg} \mathrm{N} / \mathrm{fed}\left(\mathrm{N}_{2}\right)$ & 2.11 & 3.71 & 29.21 & 16.00 & 4.00 & 9.51 & 4.37 \\
\hline $90 \mathrm{Kg} \mathrm{N} / \mathrm{fed}\left(\mathrm{N}_{3}\right)$ & 2.48 & 4.05 & 33.00 & 18.80 & 4.60 & 10.66 & 4.60 \\
\hline $120 \mathrm{Kg} \mathrm{N} / \mathrm{fed}\left(\mathrm{N}_{4}\right)$ & 2.80 & 4.39 & 34.93 & 20.60 & 4.90 & 11.88 & 4.99 \\
\hline Overall means & 2.05 & 3.61 & 31.04 & 17.30 & 4.30 & 10.01 & 4.43 \\
\hline \multicolumn{8}{|c|}{ Compost + rhizobacteria $\left(\mathrm{BO}_{4}\right)$} \\
\hline $30 \mathrm{Kg} \mathrm{N} / \mathrm{fed}\left(\mathrm{N}_{1}\right)$ & 1.16 & 2.81 & 32.00 & 14.30 & 4.00 & 9.87 & 4.54 \\
\hline $60 \mathrm{Kg} \mathrm{N} / \mathrm{fed}\left(\mathrm{N}_{2}\right)$ & 2.69 & 3.98 & 34.89 & 18.60 & 4.70 & 11.21 & 5.41 \\
\hline $90 \mathrm{Kg} \mathrm{N} / \mathrm{fed}\left(\mathrm{N}_{3}\right)$ & 3.03 & 4.85 & 37.38 & 20.30 & 5.40 & 12.30 & 5.98 \\
\hline $120 \mathrm{Kg} \mathrm{N} / \mathrm{fed}\left(\mathrm{N}_{4}\right)$ & 3.46 & 5.11 & 39.50 & 23.30 & 5.70 & 13.50 & 6.11 \\
\hline Overall means & 2.59 & 4.19 & 35.51 & 19.10 & 4.95 & 11.72 & 5.51 \\
\hline \multicolumn{8}{|c|}{ Overall means of $\mathrm{N}$-fertilizer levels } \\
\hline $\mathrm{N}_{1}$ & 0.96 & 2.44 & 28.93 & 13.00 & 3.80 & 8.92 & 4.08 \\
\hline $\mathrm{N}_{2}$ & 2.35 & 3.84 & 31.64 & 17.60 & 4.30 & 10.17 & 4.80 \\
\hline $\mathrm{N}_{3}$ & 2.71 & 4.33 & 34.69 & 19.20 & 4.90 & 11.33 & 5.08 \\
\hline $\mathrm{N}_{4}$ & 3.05 & 4.70 & 36.51 & 21.40 & 5.30 & 12.39 & 5.47 \\
\hline \multicolumn{8}{|l|}{ LSD0.05: } \\
\hline $\mathrm{N}$ & 0.27 & 0.28 & 1.82 & 1.02 & 0.34 & 0.76 & 0.45 \\
\hline $\mathrm{BO}$ & 0.27 & 0.28 & 1.82 & 1.02 & 0.34 & 0.76 & 0.45 \\
\hline $\mathrm{N} \times \mathrm{BO}$ & 0.28 & 0.63 & 3.67 & 1.59 & 0.39 & 0.97 & 0.92 \\
\hline
\end{tabular}


required at trace levels both by plant and other microorganisms (Egball and Power, 1999; Wong et al 2001; Manna et al 2003; Tejada and Conzalez, 2004 and Abdel-Wahab et al 2006).

Concerning the interaction effect between the bio-organic and mineral fertilization, data displayed that maize yield was greatly responded to mineral $\mathrm{N}$-fertilization among all studied bio-organic treatments. However, this response to $\mathrm{N}$-fertilizer was relatively acheived in presence of organic or combined bio-organic fertilization rather than solely biofertilizers or mineral fertilizer applied alone. This tendency was obtained during the two investigated seasons. For instance at the first season, the percentage increases attained in the grain yield as a result of receiving only mineral $\mathrm{N}$-fertilizer at rates of 60,90 and $120 \mathrm{Kg} \mathrm{N} /$ fed were $115.95,142.55$ and $185.11 \%$, respectively over the control treatment $(30 \mathrm{Kg} / \mathrm{fed})$. The corresponding increase values in case of manuring of soil with 5 ton/fed enriched compost recorded 106.04, 135.29 and 155.46, respectively. These percentage increases reached to $101.62,131.71$ and $174.80 \%$, respectively when the soil manuring was applied in combination with rhizobacterial inoculation. It is worthy to mention that the total crude protein content of grain and stalks behaved similarity to that obtained in grain yield. Since the application of enriched compost and rhizobacteria still showed the superiority in accumulating crude protein in grain and stalk. The average relative increases of this combined treatment were $17-89$ and $20.70 \%$, respectively, as compared with control treatment. On contrary application of rhizobacteria showed the least effect, the corresponding value of increase achieved only (3.4\%) for grains, while for stalk achieved less values than control by $1.25 \%$. The parallel values of treatment received enriched compost were on the average 17.89 and $20.87 \%$, respectively. These findings may indicate that such enriched compost only able to improve the efficiency of nitrogen fertilizer utilization (Montemurro et al 2006). Additionally, data elicited that topdressing of soil with 5 ton/fed compost with 60 or $90 \mathrm{Kg} \mathrm{N} / \mathrm{fed}$ achieved nearly the same yield of the highest mineral $\mathrm{N}$-fertilizer without compost manuring (no significant differences) indicating that the enriched compost could be partially saving the mineral fertilizer (the used enriched compost at rate of 5 ton/fed contains $86 \mathrm{Kg} \mathrm{N} / \mathrm{fed}$ ). This finding emphasized the prominent role of the compost either applied solely or in combination with rhizobacteria which may consider a precursor practice for achieving the concept of integrated fertilization strategy for increasing the yield productivity and its quality as well as reducing the risk of environment pollution. These results in accordance with those obtained by Sikora and Enkiri (2000); Wang et al (2001); Keeling et al (2003); Tejada and Gonzalez (2004) and Montemurro et al (2006), who proved the potentiality of using the organic fertilizers including the compost as a partial substitution of mineral $\mathrm{N}$-fertilizer. However, the highest yield of maize and its attributes were attained as a result of fertilization of soil with $120 \mathrm{Kg} \mathrm{N} / \mathrm{fed}$ (allocated to 7 doses) in presence of enriched compost and rhizobacteria indicating that high response of maize to fertilization, particularly in newly reclaimed soil.

\section{REFERENCES}

Abbasi, P.A.; J. Al-Dahmani; F. Sahin; H.A.J. Hoitink and S.A. Miller (2002). Effect of compost amendment on disease severity and yield of tomato in conventional and organic production system. Plant Dis., 86: 156-161.

Abbass, Z. and Y. Okon (1993). Plant growth promotion by Azotobacter paspali in the rhizosphere. Soil Boil. Biochem., 25: 1075-1083.

Abdel-Malek, Y. (1971). Free living nitrogen fixing bacteria in Egyptian soils and their possible contribution to soil fertility. Plant and Soil, Special volume, 423-442.

Abdel-Wahab, A.F. (1999). Iron-Zinc-Organic Wastes Interactions and Their Effects On Biological Nitrogen Fixation In Newly Reclaimed Soils. pp 123-130. Ph.D. Thesis, Fac. of Agric., Ain Shams Univ., Cairo, Egypt,

Abdel-Wahab, A.F. and A.S. Ahmed (2003). Preparation of bio-organic materials for their utilization as soil amendment and growth media. Annals Agric., Ain Shams Univ., Cairo, 48: 561-572.

Abdel-Wahab, A.F.; A.M. Biomy and W.M. ElFarghal (2003). Effect of some natural soil amendments on biological nitrogen fixation, growth and green yield of pea plants grown on sandy soil. Fayoum J. Agric. Res. \& Dev., 17: 47-54.

Abdel-Wahab, A.F.; G.A.A. Mekhemar; Heba Sh. Shehata and Awaref A. Hanafi (2006). Effect of plant growth bioprotecting and promoting rhizobacteria and compost on the healthy and productivity of peanut crop in sandy soil. Minifiya J. Agric. Res., 31: 1323-1348.

Abo El-Soud, A.A.; F. Sh. Badawi; Ahlam A. Mehesen and B.A. Hasouna (2006). Effect of bio and organic amendments on growth and yield of maize in newly reclaimed soil. J. Agric. Sci. Mansoura Univ., 31: 3881-3892. 
Alvarez, M.B.; S. Gagne and H. Antoun (1995). Effect of compost on rhizosphere microflora of the tomato and on the incidence of plant growth promoting rhizobacteria. Appl. Environ. Microbiol., 61: 194-199.

Bentio, M.; A. Masguer and A. Moliner (2003). Chemical and microbiological parameters for the characterization of the stability and maturity of pruning waste compost. Biol. Fertil. Soil, 37: 184189.

Bernal, M.P.; C. Paredes; M.A. SanchezMmonedero and J. Cegarra (1998). Maturity and stability parameters of composts prepared with a wide range of organic wastes. Bioresources Technology, 63: 91-99.

Bertrand, H.; R. Nalin; R. Bally and J.C. CleyetMarel (2001). Isolation and identification of the most efficient plant growth-promoting bacteria associated with canola (Brassica napus). Biol. Fertil. Soils, 33: 152-156.

Carley, H.E. and R.D. Watson (1966). A new gravimetric method for estimating root surface area. Soil Science, 102: 289-291.

Culley, J.L.B. (1993). Density and compressibility in M.R. Carter, ed. Soil Sampling and Methods of Analysis. pp. 529-539. Canadian Society of Soil Science, Lewis Publishers, Boca Raton..

Egball, B. and J.F. Power (1999). Phosphorus and nitrogen based manure and compost application: corn production and soil phosphorus. Soil Sci. Soc. Am. J., 63: 892-901.

El-Ghadban, E.A.E.; A.M. Ghallab and A.F. Abdel-Wahab (2003). Effect of organic fertilizer and biofertilization on marjoram plants under newly reclaimed soil conditions. J. Agric. Sci. Mansoura Univ., 28: 6957-6973.

Glick, B.R.; C.L. Patten; G. Holguim and D.M. Penrose (1999). Biochemical And Genetic Mechanisms Used By Plant Growth Promoting Rhizobacteria. pp. 3-7. Imperial Collage Press, London.

Harada, Y. and A. Inoko (1980). The measurement of cation-exchange capacity of compost for the estimation of the degree of maturity. Soil Sci. Plant Nutri., 26: 127-134.

Hoitink, H.A.J. and C. Changa (2004). Production and utilization guidelines for disease suppressive compost. Acta Hortic., 635: 87-92.

Hoitink, H.A.J. and M.J. Boehm (1999). Biocontrol within the context of soil microbial communities, a substrate dependent phenomenon. Annal Review of Phytopathology, 37: 427-446.
Iglesias-Jimenez, E. and V. Perez-Garcia (1989). Evaluation of city refuse compost maturity: A Review. Biological Wastes, 27: 115-142.

Iglesias-Jimenez, E. and V. Perez-Garcia (1992). Determination of maturity indices for city refuse compost. Agric. Ecosyst. Environ., 38: 311-343.

Jackson, M.L. (1973). Soil Chemical Analysis. pp122-128. Prentice. Hall of India Private Limited, New Delhi.

Jann, G.J.; D.H. Howard and A.J. Solle (1959). Methods for determination of completion of composting. Appl. Microbial, 7: 271-275.

Keeling A.A.; K.R. McCallum and C.P. Beckwith (2003). Mature green waste compost enhances growth and nitrogen uptake in wheat (Triticum aestivum L.) and oilseed rape (Brassica napus L.) through the action of water-extractable factors. Bioresources Technology, 90: 127- 132.

Kloepper, J.W. (1993). Plant growth promoting rhizobacteria as biological control agents. In B. Metting, ed., Soil Microbial Technologies. pp. 255-274. Marcel Dekker, New York,.

Kokalis-Burelle, N.; J.W. Kloepper and M.S. Reddy (2006). Plant growth promoting rhizobacteria as transplant amendments and their effects on indigenous rhizosphere microorganisms. Applied Soil Ecology, 31: 91-100.

Manna, M.C.; P.K. Ghosh and T.K. Ganguly (2003). Comparative performance of four sources of enriched phosphocompost and inorganic fertilizer application on yield, uptake of nutrients and biological activity of soil under soybean-wheat rotation. Food, Agriculture \& Environment, 2: 203208.

Mantelin, S. and B. Touraine (2004). Plant growth promoting bacteria and nitrate availability: impacts on root development and nitrate uptake. J. Exp. Bot., 55: 27-34.

Mathur, S.P.; G. Owen; H. Dinel and M. Schnitzer (1993). Determination of compost biomaturity, Literature review, Biol. Agric. Hortic., 10: 65-85.

Montemurro, F.; M. Maiorana; D. Ferri and G. Convertini (2006). Nitrogen indicators, uptake and utilization efficiency in a maize and barley rotation cropped at different levels and sources of $\mathrm{N}$ fertilization. Field Crops Res., 99: 114-123.

Morel, J.L.; F. Colin; J. Germon; P. Godin and C. Juste (1985). Methods for the evaluation of the maturity of municipal refuse compost. In: composting of Agricultural and Other Wastes. pp. 56-72. ed. J.K.R. Gasser. Elsevier Applied Science Publisher, London \& New York. 
Page, A.L.; R.H. Miller and D.R. Keeney (1982). Methods of Soil Analysis. II., Chemical and Microbiological Properties. $2^{\text {nd }}$ Ed. Madison, Wisconsim, USA.

Piper, C.S. (1950). Soil and Plant Analysis. 1st Ed. pp. 30-229. Interscience Publishers Inc., New York.

Riad, A. (1982). Potential sources of organic matter in Egypt. FAO Soil Bull., No. 45, FAO, Rome. Rodrigues, A.M.; L.J. Ferrereira; A.L. Fernando; P. Urbano and J.S. Oliveira (1995). Cocomposting of sweet sorghum biomass with different nitrogen sources. Biochem. Technol., 54: 2127.

Ryckeboer, J.; J. Mergaert; K. Vaes; S. Klammer; D. De Clercq; J. Coosemans; H. Insam and J. Swings (2003). A survey of bacteria and fungi occurring during composting and self-heating processes. Annales of Microbiol., 53: 349-410.

Rynk, R. (Editor) (1992). On Farm Composting Handbook. pp. 23-35. NRAES-54. Northeast Regional Agricultural Engineering Service, Cooperative Extension. Ithaca, N.Y.

Senesi, N. (1989). Composted material as organic fertilizers. Sci. Total Environ., 81/82: 521-542.

Sikora, L.J. and N.K. Enkiri (2000). Efficiency of compost-fertilizer blends compared with fertilizer alone. Soil Sci., 165: 444-541.

Smith, D.C.; V. Beharee and J.C. Hughes (2001). The effect of compost produced by a simple composting procedure on the yield of swiss chard (Beta vulgaris $\mathrm{L}$. var flavescens) and common bean (Phaseollas vaulgaris L. var. nanus). Scientia Hortic. 91: 393-406.
Snedecor, G.W. and W.G. Cochran (1980). Statistical Methods, Seventh Ed. pp. 255-269. lowa State University Press, Ames, USA.

Tejada, M., and J.L. Gonzalez. (2004). Effects of application of a byproduct of the two-step olive oil mill process on maize yield. Agron. J., 96: 692699.

Van-Heerden, I.; C. Cronie; S.H. Swort and J.M. Kotze (2002). Microbial, chemical and physical aspects of citrus waste composting. Bioresources Technology, 81: 71-76.

Van-Loon L.C. and P.A.H.M. Bakker (2003). Signalling in rhizobacteria-plant interactions. Ecological Studies, 68: 290-330.

Vessey, K.J. (2003). Plant growth promoting rhizobacteria as biofertilizers. Plant and Soil, 255: 571-586.

Wang, P.; C.M. Changa; M.E. Watson; W.A. Dick; Y. Chen and H.A.J. Hoitink (2004). Maturity indices for composted dairy and pig manure. Soil Biol. Biochem., 36: 767-776.

Wong, J.W.C.; K.F. Mak; N.W. Chan; A. Lam; M. Fag; L.X. Zhou; Q.T. Wu and X.D. Liao (2001). Co-composting of soybean residue and leaves in Hong Kong. Bioresources Technology, 76: 99106.

Wu, L. and L.O. Ma (2001). Effects of sample storage on biosolids compost stability and maturity evaluation. J. Environ. Qual 30: 222-228.

Wu, L.; L.O. Ma and G.A. Martinz (2000). Comparison of methods for evaluating stability and maturity of biosolids compost. J. Environ. Qual, 29: 424-429.

Zucconi, F.; M. Forte; A. Monoc and M. Beritodi (1981). Biological evaluation of compost maturity. Bicycle, 22: 27-29. 